Partial Purification and Thermal Stability of Two Peroxidases from Pithecellobium dulce (Roxb.) Benth. Aril

Julião, M. M. S.; Oliveira, S. T.; Andrade, L. B. S; Figueiredo, M. F.; Salles, H. 0.

Rev. Virtual Quim., 2016, 8 (6), 1913-1923. Data de publicação na Web: 26 de dezembro de 2016

http://rvq.sbq.org.br

Purificação Parcial e Estabilidade Térmica de Duas Peroxidases Extraídas de Arilos de Pithecellobium dulce (Roxb.) Benth.

Resumo: Duas formas de peroxidase (POX), denominadas PdPI e PdPII, foram parcialmente purificadas de arilos de Pithecellobium dulce, utilizando precipitação com sulfato de amônio e cromatografia de troca iônica. O zimograma das proteínas obtidas após precipitação com sulfato de amônio na faixa de 60 a 90\% de saturação (fração F6090), mostrou duas bandas com atividade peroxidásica. Na coluna de celulose $\mathrm{DE}-52$, a atividade peroxidásica foi

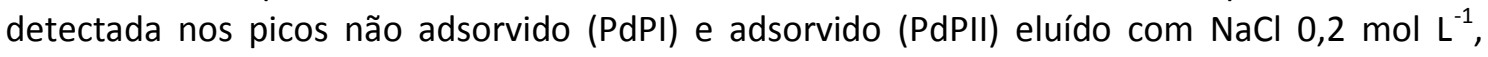
sugerindo que a PdPI ( $114 \mathrm{KDa})$ e a PdPII ( 77 KDa) são proteínas básicas e ácidas, respectivamente, sendo a PdPI estável a 80 ㄷ. Este é o primeiro relato de purificação parcial de POX obtida de arilos de $P$. dulce, indicando que esta espécie pode ser uma nova fonte de enzimas para utilização em biossensores e outras aplicações biotecnológicas.

Palavras-chave: Enzimas; Atividade peroxidásica; P. dulce; Zimograma.

\title{
Abstract
}

Two peroxidase (POX) forms, named PdPI and PdPII, were partially purified from the Pithecellobium dulce aril, using ammonium sulfate precipitation and anion exchange chromatography. Zymography of the proteins obtained after precipitation in the range of 60$90 \%$ ammonium sulfate (F6090 fraction) showed two bands with peroxidase activity. In DE-52 cellulose column, the peroxidase activity was detected in unadsorbed peak (PdPI) and adsorbed peak eluted with $0.2 \mathrm{~mol} \mathrm{~L}^{-1} \mathrm{NaCl}$ (PdPII) suggesting that PdPI ( $\left.\sim 114 \mathrm{KDa}\right)$ and PdPII

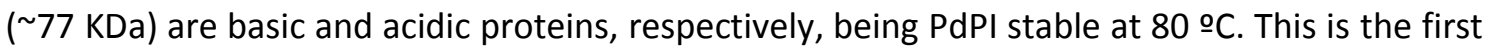
report of partial purification of POX from $P$. dulce aril, indicating that this species may be a new source of enzymes for use in biosensors and other biotechnological applications.

Keywords: Enzymes; Peroxidases activity; P. dulce; Zymography.

* Universidade Estadual Vale do Acaraú, Coordenação de Química, Avenida da Universidade, 850 Betânia, CEP 62040-370, Sobral-CE, Brazil.

$M$ murilo-sergio@uol.com.br

DOI: $\underline{10.21577 / 1984-6835.20160130}$ 


\section{Partial Purification and Thermal Stability of Two Peroxidases from Pithecellobium dulce (Roxb.) Benth. Aril

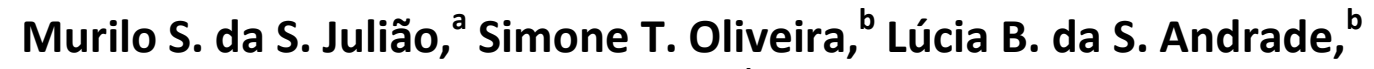 \\ Marlene F. Figueiredo, ${ }^{b}$ Hévila O. Salles ${ }^{c}$
}

\footnotetext{
a Universidade Estadual Vale do Acaraú, Departamento de Química, Avenida da Universidade, 850, Betania, CEP 62040-370, Sobral-CE, Brazil.

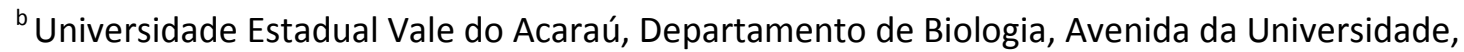
850 Betania, CEP 62040-370, Sobral-CE, Brazil.

`Embrapa Caprinos e Ovinos, Sobral, Ceará, Brasil. Rodovia Sobral/Groaíras, Km 04, CEP 6201097, Sobral-CE, Brazil.

* murilo-sergio@uol.com.br
}

Recebido em 21 de março de 2016. Aceito para publicação em 26 de dezembro de 2016

1. Introduction

2. Experimental

3. Results and Discussion

4. Conclusions

\section{Introduction}

Peroxidase (EC 1.11.1.7) is a hemecontaining enzyme that utilizes hydrogen peroxide $\left(\mathrm{H}_{2} \mathrm{O}_{2}\right)$ to oxidize a wide variety of organic and inorganic compounds, ${ }^{1}$ but has also been shown to generate $\mathrm{H}_{2} \mathrm{O}_{2}$ under high $\mathrm{pH}$ conditions, particularly during biotic interactions. $^{2-4}$

Plant peroxidases (POX) are usually found in roots, ${ }^{4}$ latex, ${ }^{5}$ flowers, ${ }^{6}$ leaves, ${ }^{5}$ seeds and fruits. ${ }^{7,8}$ They are present in multiple ionic forms and their in vivo functions include cellular growth, the synthesis of cell walls, fruit growth and ripening, hormone regulation, lignification, senescence and defense mechanisms against abiotic and biotic stress. $^{2-4}$

Various types of POX can be found in the same plant species and these may differ significantly in molecular weight, substrate specificity and thermal stability. ${ }^{2}$ According to their isoelectric points (pls), they are usually classified as acidic, neutral or basic. ${ }^{9}$

Peroxidases are important enzymes in analytical biochemistry. They are used in industrial applications due to their catalytic properties, thermal stability, and versatility, being useful for recognizing various substrates. Thus, peroxidases have potential applications in different areas, which increase the appeal of studying these enzymes. In addition, plants as sources of enzymes has become a promising field of study, because of the simplicity and ease of obtaining this 
biological material. ${ }^{4,5}$ Currently, horseradish peroxidase is one of the most widely used enzymes for the construction of organic biosensors and diagnostic test kits for glucose and cholesterol blood level sensors. ${ }^{10-13}$ However, additional plant species should also be investigated in order to identify novel peroxidases with commercial value.

Pithecellobium dulce (Roxb.) Benth. (Fabaceae: Mimosoideae) is an evergreen tree from tropical and subtropical America that has now become a pan-tropical species. ${ }^{14}$ In countries such as Mexico and India, seeds have been used as both a food source and livestock feed. ${ }^{15,16}$ In alternative medicine, infusions of different parts of this species have been used to treat various diseases including intestinal disorders and ulcers. ${ }^{16-18}$

Although there is literature regarding research on the chemical constituents of seeds and leaves of the $P$. dulce,,$^{19-21}$ there are still several aspects of the isolation and characterization of these compounds that remain unexplored.

In Brazil's semiarid regions, plants may present compounds of great biotechnological interest, which are traditionally used for medicinal and nutritional purposes. ${ }^{22-24} P$. dulce is well adapted to Brazilian semiarid environments and widely distributed throughout Ceará's State, where it is popularly known as "mata-fome". ${ }^{25}$

The fruit of this legume is a pod, 10 to 15 $\mathrm{cm}$ long, and dehiscent on both sides. Each pod contains 5-10 shiny black seeds, which are surrounded by a sweet white or pink aril. ${ }^{14}$ The aril is a good source of antioxidants, hepatoprotective, and flavonoids compounds. ${ }^{16,26,27}$ In some countries, the aril is consumed uncooked with salt, pepper and lemon or in fruit juices. ${ }^{15,26}$ In Ceará's State, the aril is commonly eaten by the local population, mainly by children.

$P$. dulce is widespread and grows in abundance in northeastern Brazil, and no studies have reported the presence of peroxidase in the species. Thus, to obtain a new peroxidase with potential analytical applications, in this work we aimed to effect the extraction, isolation, and evaluation of the thermal stability of this enzyme from the P. dulce aril.

\section{Experimental}

P. dulce fruits were collected on campus of the Universidade Estadual Vale do Acaraú, Sobral-CE, Brazil, and identified at the Herbarium Prof. Francisco de Abreu Matos. To obtain soluble peroxidase, arils (10.00 g) were isolated manually from black seed and homogenized in a blender for 5 minutes in cold $34 \mathrm{mM}$ phosphate buffer $(\mathrm{pH}$ 6.7), containing polyvinylpolypyrrolidone (1:4:0.1 $w / v / w$, respectively). Homogenate was filtered through cheesecloth and centrifuged at $10,000 \times g$ for $30 \mathrm{~min}$ at $4{ }^{\circ} \mathrm{C}$. Supernatant, denominated crude extract of arils (EaPd), was subjected to $0-30 \%, 30-60 \%$, and $60-90 \%$ ammonium sulfate fractionation. Precipitate of each fraction named F030, F3060 and F6090 corresponding to each band saturation, respectively, was collected by centrifugation, dissolved and dialyzed against water, lyophilized and stored at $-4{ }^{\circ} \mathrm{C}$ until use. Twenty milligram the $\mathrm{F} 6090$ was dissolved in $2.0 \mathrm{~mL}$ of tris/ $\mathrm{HCl} 50 \mathrm{mM}(\mathrm{pH}$ 7.5) and applied to a DE-52 cellulose anionicexchange column $(10 \times 1.5 \mathrm{~cm})$ equilibrated with same buffer. Elution was carried out at a

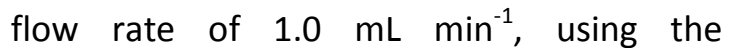
equilibrium buffer. Retained peaks were eluted with $\mathrm{NaCl}$ solution at concentrations of 0.2 and $0.4 \mathrm{M}$ in a step-wise manner. Peaks containing a peroxidase activity were dialyzed against phosphate buffer and used in the assays.

Protein concentration was determined by the Coomassie brilliant blue G-250 method, using bovine serum albumin as standard. ${ }^{28}$ Absorbance at $280 \mathrm{~nm}$ was followed spectrophotometrically and used to monitor protein elution profiles during chromatographies.

Guaiacol (2-methoxyphenol) and 
hydrogen peroxide were used as substrates for spectrophotometric quantification of peroxidase. ${ }^{29}$ The reaction mixture containing $2.7 \mathrm{~mL}$ of $50 \mu \mathrm{M}$ guaiacol, $100 \mu \mathrm{L}$ of $13 \mathrm{mM}$ $\mathrm{H}_{2} \mathrm{O}_{2}$ in $34 \mathrm{mM}$ phosphate buffer $(\mathrm{pH} 6.7)$ and $200 \mu \mathrm{L}$ of enzyme extracts or fractions was monitored for 10 minutes in a spectrophotometer at $470 \mathrm{~nm}$ with readings at every 30 seconds. One unit (U) of peroxide activity corresponded to the amount of enzyme which caused a change of 0.1 in absorbance at $470 \mathrm{~nm}$. All assays were performed in triplicate, and the results were expressed as specific activity (U.mg ${ }^{-1}$ ).

SDS polyacrylamide (12.5\%) gel electrophoresis (SDS-PAGE) in the absence of $\beta$-mercaptoethanol was conducted as described by Laemmli at $4{ }^{\circ} \mathrm{C} .{ }^{30}$ Proteins were detected by staining with $0.1 \%$ Coomassie brilliant blue G-250. Molecular weight was calculated by linear regression using a standard marker. Gels were stained for peroxidases (zymography) as described by Caruso et al. ${ }^{31}$ with some modifications: after SDS-PAGE, gel was washed for 2 times, 10 min each, with $0.2 \%$ Triton X-100. Next, gels were soaked for $30 \mathrm{~min}$ in $50 \mathrm{mM}$ sodium acetate buffer ( $\mathrm{pH}$ 5.2). Then, gel was transferred to a solution containing $0.03 \%$ $\mathrm{H}_{2} \mathrm{O}_{2}(\mathrm{v} / \mathrm{v}), 0.2 \%$ guaiacol $(\mathrm{v} / \mathrm{v})$ and $0.01 \% 3-$ amino-9-etil-carbazol $(\mathrm{w} / \mathrm{v})$ in the acetate buffer, until visible brown bands appeared. Subsequently, gel was washed with distilled water to stop the reaction.

In order to determine the thermal stability of the POX, $1.0 \mathrm{~mL}$ of the peaks with peroxidase activity from the column of DE-52 cellulose were incubated for 10 minutes in water bath at 25 (room temperature), 40, 50,

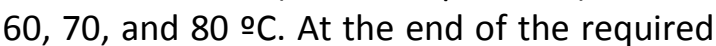
time, the enzyme was cooled in an ice bath and brought to room temperature. The residual guaiacol-peroxidase activity was determined spectrophotometrically. ${ }^{29}$ The residual percentage of the enzyme activity was calculated by comparison with unheated enzyme.

\section{Results and Discussion}

Currently, extensive investigations to characterize the occurrence, thermal and $\mathrm{pH}$ stability, substrate specificity and technological applications of enzymes presented in crude extract or purified fractions from plants are being carried out. $^{32,33}$ Chemical investigations of the different parts of the plant have resulted in the detection and isolation of a interesting enzymes, some of which having promising applications in the industrial and medical areas. $^{34-37}$

In this study, we investigated the activity of POX in aqueous extracts of the $P$. dulce aril (EaPd) and two peroxidases were partially isolated using ammonium sulfate precipitation and ion-exchange chromatography. The EaPd showed 0.299 $\mathrm{mg} \cdot \mathrm{mL}^{-1}$ of the soluble protein and peroxidase enzyme with a specific activity of 1,928 U. $\mathrm{mg}^{-1}$. P. dulce aril is rich in tannins, flavonoids, antioxidants saponins, anthocyanin and although they have about $12 \%$ of protein there is no report of the bioactive enzymes identification, such as peroxidases, in $P$. dulce aril. ${ }^{16,26}$ As is our knowledge, there is an account of only two proteins isolated from seeds of these species, namely, a lysozyme of $14.4 \mathrm{KDa}$ with antifungal activity and a Kunitz-type protein inhibitor of $19.9 \mathrm{KDa} .^{19,38}$

For the partial purification of POX enzyme, proteins of the EaPd were precipitated with ammonium sulfate, resulting in three fractions, F030, F3060, and F6090, respective for each band of saturation. The F030 no showed enzymatic activity. Fractions F3060 and F6090 showed activity for POX, and a greater specific activity was found in fraction F6090 (1,940 U. $\mathrm{mg}^{-1}$ ) compared to F3060 $\left(430 \mathrm{U}^{\mathrm{mg}}{ }^{-1}\right)$. The presence of POX activity in both fractions suggests the existence of at least two forms of peroxidase in $P$. dulce aril.

Plants peroxidase can occurs in multiple molecular forms and being present in soluble 
and bound forms (ionically and covalently bound) and each enzyme can shows variable amino acid sequences, diverse expression profiles, molecular weights and catalyze reactions with different substrates. ${ }^{39-41}$ For example, this diversity of forms of peroxidases have been found at cucumber peelings, which showed two isoforms, ${ }^{42}$ at tomato fruits, which showed four isoforms, ${ }^{43}$ at broccoli stems, which showed three isoforms, $^{44}$ at horseradish root, which showing seven isoforms and at coconut endosperm, which showed two isoforms. ${ }^{45,46}$ Peroxidase is a key enzyme in controlling plant differentiation and development, and one possible reason for the occurrence of multiple forms of POX is the diversity of biological functions and importance of POX to the growth and self-defense of plants. ${ }^{39,47,48}$
Aiming to separate the two forms of POX from F6090 fraction, which showed a greater specific activity, the fraction was passed through an anion exchange column (DE-52 cellulose). As observed in Figure 1 , the peroxidase activity was observed in the unadsorbed proteins (fractions 2-3, peak I) and adsorbed peak eluted with $0.2 \mathrm{~mol} \mathrm{~L}^{-1}$ $\mathrm{NaCl}$ (factions 14-16, peak II), thus indicating that a unretained protein, named PdPI, has positive charges predominate at the surface of the enzyme. On the other hand, the adsorbed protein (PdPII) has a predominance of negative charge in their surface. This elution profile suggested that PdPI and PdPII are basic and acidic proteins, respectively. Similar elution characteristics were reported from POX from broccoli peroxidases when loaded onto DEAE-Sephacel, an anion exchange chromatography. ${ }^{44}$

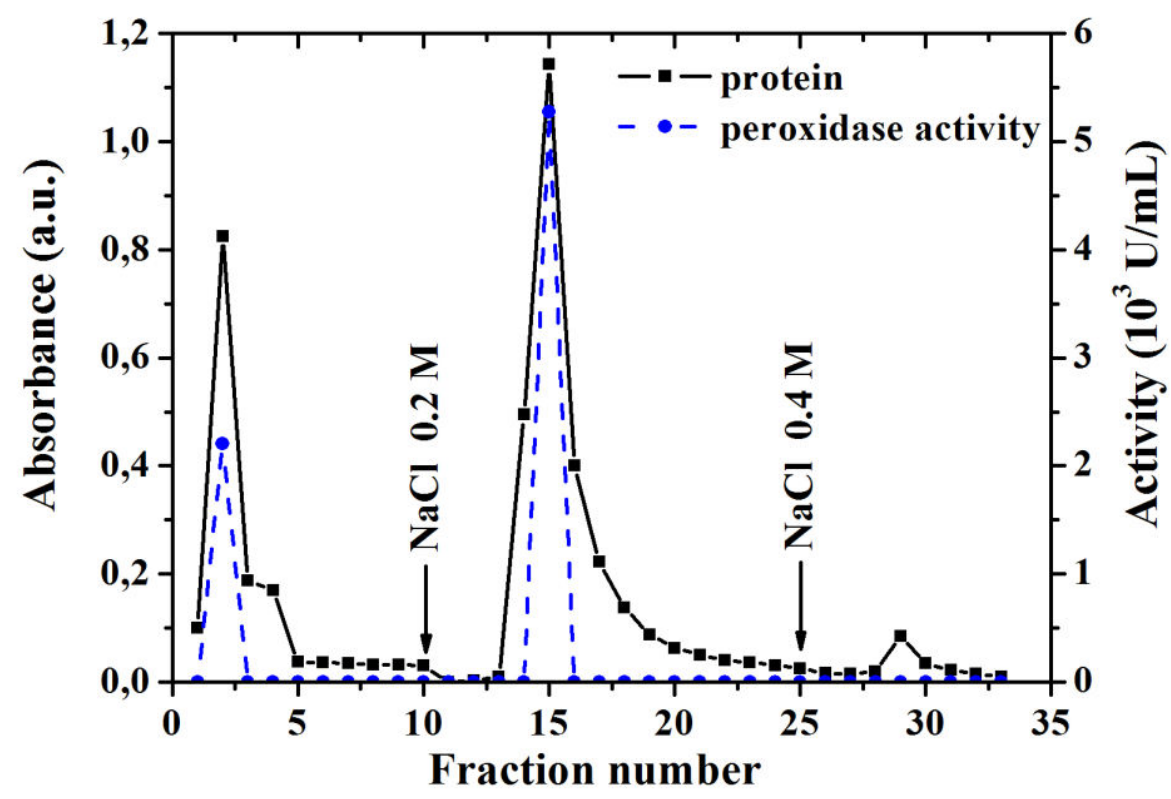

Figure 1. Elution profile from DE-52 cellulose anionic column of the F6090 fraction of the $P$. dulce arils. Protein concentration was monitored at $280 \mathrm{~nm}$ and peaks were assayed for peroxidase activity. All measurements were performed in triplicate

As shown in Table 1, the PdPI was characterized by a high specific activity $\left(10,369\right.$ U. $\left.\mathrm{mg}^{-1}\right)$ when compared to the PdPII $\left(6,394 \mathrm{U} \cdot \mathrm{mg}^{-1}\right) \cdot \mathrm{PdPI}$ and PdPII was purified to 5.3 and 3.3 folds with overall recovery of $25 \%$ and $91 \%$, respectively. PdPII total activities units were similar than those isolated from other plant sources, for example, Copaifera langsdorffii leaves, and broccoli stems. ${ }^{5,44}$ 
Table 1. Purification summary of peroxidase (POX) extracted from Pithecellobium dulce arils

\begin{tabular}{cccccc}
\hline $\begin{array}{c}\text { Purification } \\
\text { step }\end{array}$ & $\begin{array}{c}\text { Total protein } \\
(\mathbf{m g})\end{array}$ & $\begin{array}{c}\text { Total activity } \\
\text { units (U) }\end{array}$ & $\begin{array}{c}\text { Specific activity } \\
\left(\mathbf{U} \cdot \mathbf{m g}^{-1}\right)\end{array}$ & $\begin{array}{c}\text { Purification } \\
\text { (fold) }\end{array}$ & $\begin{array}{c}\text { Yield } \\
\text { (\%) }\end{array}$ \\
\hline Crude extract & 35.9 & 69,213 & 1,928 & 1.0 & 100 \\
F6090 & 20.6 & 39,964 & 1,940 & 1.0 & 57 \\
PdPI $^{\text {a }}$ & 1.7 & 17,628 & 10,369 & 5.3 & 25 \\
PdPII $^{b}$ & 9.9 & 63,300 & 6,394 & 3.3 & 91 \\
\hline
\end{tabular}

${ }^{a}$ Unadsorbed (PdPI) and ${ }^{b}$ adsorbed peroxidases (PdPII) in anionic exchange column (DE-52 cellulose); F6090, 60-90\% ammonium sulfate fraction.

PdPI and PdPII was subjected to SDS-PAGE and zymography for peroxidase (Fig. $2 \mathrm{~A}$ and $2 \mathrm{~B}$, respectively) and the electrophoretic profile of proteins showed that the anion exchange chromatography was effective in separating the two forms of POX. Partially isolated PdPI and PdPII has $\sim 114 \mathrm{KDa}$ and $\sim 77$ KDa molecular weight (MW), respectively, as estimated by linear regression using a standard marker.
(A)

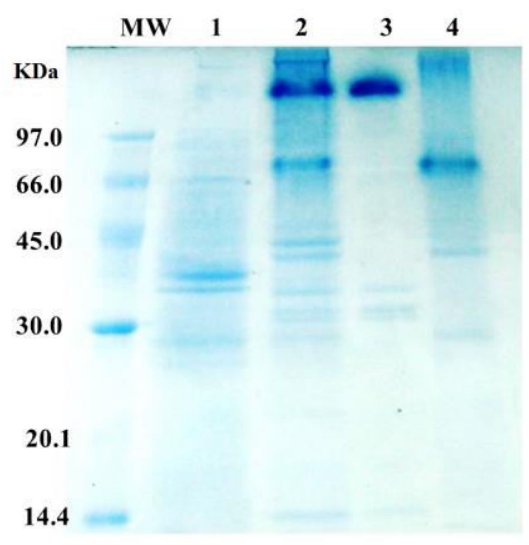

(B)

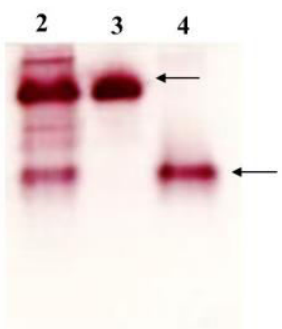

Figure 2. SDS-PAGE (A) and zymography pattern (B) of proteins from $P$. dulce aril: (1) crude extract (EaPd), (2) F6090 fraction, (3) PdPI (unadsorbed proteins in DE-52 column), (4) PdPII (adsorbed proteins in DE-52 column), (MW) molecular weight markers LMW-SDS (GE Healthcare). Fifty micrograms of protein was added to each well. The arrows indicate the bands with peroxidases activity

It is interesting to note that the molecular weight found for PdPI and PdPII is very higher than those reported for most peroxidases isolated from plant sources, namely, oil palm leaf $(48 \mathrm{KDa}),{ }^{49}$ sweet potato peel $(37 \mathrm{KDa}),{ }^{50}$ broccoli stems $(\mathrm{KDa}){ }^{44}$ windmill palm leaf $(50$ $\mathrm{KDa}){ }^{51}$ black gram's husk (35 KDa), ${ }^{52}$ horseradish root $(42 \mathrm{KDa}){ }^{45}$ coconut endosperm $(\sim 47 \mathrm{KDa}) .{ }^{46}$ These peroxidases are frequently found as monomeric proteins with molecular weights ranging from $35 \mathrm{KDa}$ to $50 \mathrm{KDa}{ }^{42,52,53}$

Although less frequent, there are reports of peroxidase with a molecular weight above at $100 \mathrm{KDa}$ and this is due they be constituted as homo- or hetero- dimeric, 
trimeric ou tetrameric proteins, such as those found in leucaena stem $(200 \mathrm{KDa}),{ }^{54}$ papaya fruit ( $240 \mathrm{KDa})$ and bamboo shoots (111 $\mathrm{KDa}){ }^{55,56}$ Thus, the high molecular weight found in PdPI and PdPII may suggest that this is multimeric enzymes but further studies are needed to confirm this speculation.

Thermal stability of the two partially isolated peroxidases was evaluated at $\mathrm{pH} 6.7$ in room ambient temperatures and between 40 and $80 \stackrel{\circ}{ } \mathrm{C}$, incubated for 10 minutes. The PdPII was heat-labile in the temperature range of 60 to 80 ㅇ $\mathrm{C}$ with a fast inactivation at $60 \stackrel{\circ}{\circ}$ (Fig. 3). This loss of activity at temperatures above $50{ }^{\circ} \mathrm{C}$ also been observed for peroxidases of Copaifera langsdorffii leaves, coconut endosperm, and rocket leaves. ${ }^{5,46,57}$

On the other hand, the activity in PdPI remains almost constant in the temperature until $60 \stackrel{\circ}{\circ}$. It showed mild decreases ( 30\%) in its activity at the temperature range of 70 to $80 \stackrel{\circ}{ } \mathrm{C}$. Although peroxidase has been recognized as of the most heat-stable enzymes in plants, ${ }^{58}$ the fact of PdPI retain approximately $70 \%$ of its activity after $10 \mathrm{~min}$ incubation at $80{ }^{\circ} \mathrm{C}$ and $\mathrm{pH} 6.7$, showed that $\mathrm{PdPI}$ was more resistant to heating than horseradish peroxidase, the only traditional commercial source of POX..$^{59}$ However, highly stable peroxidases can be found in Moringa oleifera, and Phoenix dactylifera L. leaves peroxidases which are among the most thermostable peroxidase described in the literature. ${ }^{58,60}$

It is noteworthy that the thermal stability of peroxidases may depend on the exposure time, the nature of the substrate employed, to the particular enzyme structure as the assayed conditions, especially the $\mathrm{pH}^{46,48,57}$ For example, the peroxidase from Elaies guineensis leaves (African oil palm tree) is a highly stable enzyme at ambient temperature over a broad range from $\mathrm{pH} 2.0$ to $12 .{ }^{49}$ The increasing temperature up to 70 o $\mathrm{C}$ has no effect on their stability, after 1 hour of incubation, at $\mathrm{pH}$ 7.5. However, combination of the temperature at $70 \stackrel{\circ}{ } \mathrm{C}$ with acidic $(\mathrm{pH}$ 3.0) or alkaline ( $\mathrm{pH} \mathrm{12)} \mathrm{conditions} \mathrm{decreases}$ dramatically their activity. ${ }^{59}$

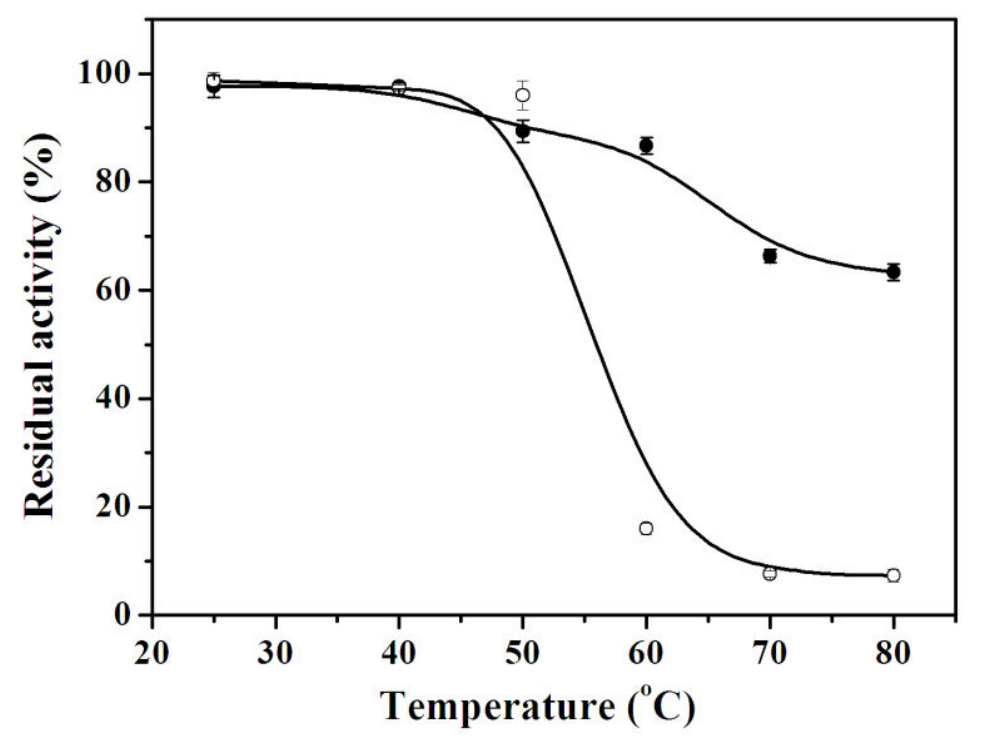

Figure 3. Residual activity of two peroxidases from Pithecellobium dulce aril after thermal treatment (40 to $80{ }^{\circ} \mathrm{C}$ for $10 \mathrm{~min}$.). PdPI cationic peroxidase (-ш-) and PdPII, anionic peroxidase (-o-). The percentage of the residual activity was calculated by comparison with the enzyme activity at room temperature $\left(25^{\circ} \mathrm{C}\right)$. The software Origin 8.1 (OriginLab, Northampton, MA) was used for the calculation of the means and standard deviation 


\section{Conclusions}

In conclusion, the $P$. dulce aril, a legume used as a food source, contains multiple forms of peroxidase, and the isolation and characterization of two of its forms was first reported in this study. That PdPI was stable a high temperature indicates that this POX may be a new source of enzyme suitable for use in biosensors and other biotechnological applications.

\section{Acknowledgments}

The authors thank the Ceará Foundation for Scientific and Technological Development (FUNCAP) and the National Council for Scientific and Technological Development (CNPq) for scholarships, and financial support.

\section{References}

${ }^{1}$ Veitch, N. C. Horseradish peroxidase: a modern view of a classic enzyme. Phytochemistry 2004, 65, 249. [CrossRef]

${ }^{2}$ Kumar, R.; K.A. Singh, K. A.; Singh, V. K.; Jagannadham M. V. Biochemical characterization of a peroxidase isolated from Caribbean plant: Euphorbia cotinifolia. Process Biochemistry 2011, 46, 1350. [CrossRef]

${ }^{3}$ Chen, L.-C.; Chung, Y.-C.; Chang, C.-T. Characterisation of an acidic peroxidase from papaya (Carica papaya L. cv Tainung No. 2) latex and its application in the determination of micromolar hydrogen peroxide in milk. Food Chemistry 2012, 135, 2529. [CrossRef] [PubMed]

${ }^{4}$ Lavery, C. B.; Maclnnis, M. C.; MacDonald, M. J.; Williams, J. B.; Spencer, C. A.; Burke, A.A.; Irwin, D. J.; D'Cunha, G. B. Purification of peroxidase from Horseradish (Armoracia rusticana) roots. Journal of Agricultural and Food Chemistry 2010, 58, 8471. [CrossRef] [PubMed]

${ }^{5}$ Maciel, H. P. F.; Gouvêa, C. M. C. P.; Toyama, M.; Smolka, M.; Marangoni, S.; Pastore, G. M. Extraction, purification and biochemical characterization of a peroxidase from Copaifera langsdorffii leaves. Química Nova 2007, 30, 1067. [CrossRef]

${ }^{6}$ López-Molina, D.; Heering, H. A.; Smulevich, G.; Tudela, J.; Thorneley, R. N.; GarcíaCánovas, F.; Rodríguez-López, J. N. Purification and characterization of a new cationic peroxidase from fresh flowers of Cynara scolymus L. Journal of Inorganic Biochemistry 2003, 94, 243. [CrossRef] [PubMed]

${ }^{7}$ Zia, M. A.; Kouzar, M.; Ahmed, I.; Iqbal, H. M. N.; Abbas, R. Z. Comparative study of peroxidase purification from apple and orange seeds. African Journal of Biotechnology 2011, 10, 6300. [CrossRef]

${ }^{8}$ Neves, V. A. Ionically bound peroxidase from peach fruit. Brazilian Archives of Biology and Technolology 2002, 45, 7. [CrossRef]

${ }^{9}$ Yoshida, K.; Kaothien, P.; Matsui, T.; Kawaoka, A.; Shinmyo, A. Molecular biology and application of plant peroxidase genes. Applied Microbiology and Biotechnology 2003, 60, 665. [CrossRef] [PubMed]

${ }^{10}$ Almagro, L.; Gómez Ros, L. V.; BelchiNavarro, S.; Bru, R.; Ros Barceló, A.; Pedreño, M. A. Class III peroxidases in plant defense reactions. Journal of Experimental Botany 2009, 60, 377. [CrossRef] [PubMed]

${ }^{11}$ Litescu, S. C.; Eremia, S.; Radu, G. L. Biosensors for the determination of phenolic metabolites. Advances in Experimental Medicine and Biology 2010, 698, 234. [CrossRef] [PubMed]

${ }^{12}$ Hamid, M.; Khalil-ur-Rehman. Potential applications of peroxidases. Food Chemistry 2009, 115, 1177. [CrossRef]

${ }^{13}$ Regalado, C.; García-Almendárez, B. E.; Duarte-Vázquez, M. A. Biotechnological 
applications of peroxidases. Phytochemistry Reviews 2004, 3, 243. [CrossRef]

${ }^{14}$ Le Houeron, H. Pithecellobium dulce (Roxb.) Benth. Available at: $<$ http://www.fao.org/ag/agp/AGPC/doc/gbas e/DATA/pf000410.htm>. Accessed in: March 2016. [Link]

${ }^{15}$ Monroy, R.; Colín, H. El guamúchil Pithecellobium dulce (Roxb.) Benth, un ejemplo de uso múltiple. Madera y Bosques 2004, 10, 35. [Link]

${ }^{16}$ Pío-León, J. F.; Díaz-Camacho, S. P.; Montes-Avila, J.; López-Angulo, G.; DelgadoVargas, F. Nutritional and nutraceutical characteristics of white and red Pithecellobium dulce (Roxb.) Benth fruits. Fruits 2013, 68, 397. [CrossRef]

${ }^{17}$ Megala, J.; Geetha, A. Antiulcerogenic activity of hydroalcoholic fruit extract of Pithecellobium dulce in different experimental ulcer models in rats. Journal of Ethnopharmacology 2012, 142, 415. [CrossRef] [PubMed]

${ }^{18}$ Olivares-Pérez, J.; Avilés-Nova, F.; AlbarránPortillo, B.; Castelán-Ortega, O. A. RojasHernández, S. Nutritional quality of Pithecellobium dulce and Acacia cochliacantha fruits, and its evaluation in goats. Livestock Science 2013, 154, 74. [CrossRef]

${ }^{19}$ Delgado-Vargas, F.; López-Valdés, H. E.; Valdés-Rodrigues, S. Blanco-Labra, A.; Chagolla-López, A.; Lópes-Valenzuela E. J. Isolation and properties of a Kunitz-type protein inhibitor obtained from Pithecellobium dulce seeds. Journal of Agricultural and Food Chemistry 2004, 52, 6115. [CrossRef] [PubMed]

${ }^{20}$ Katekhaye, S. D.; Nagmoti, D. M. $\alpha-$ Glucosidase and $\alpha$-amylase inhibitory activities of Pithecellobium dulce bark and leaves. Phytopharmacology 2013, 4, 123. [Link]

${ }^{21}$ Govindarajan, M.; Rajeswary, M.; Sivakumar, R. Larvicidal \& ovicidal efficacy of Pithecellobium dulce (Roxb.) Benth. (Fabaceae) against Anopheles stephensi Liston \& Aedes aegypti Linn. (Diptera:
Culicidae). The Indian Journal of Medical Research 2013, 138, 129. [PubMed]

${ }^{22}$ Santos, P. H. A.; Santos, I. S.; Melo, V. M. M.; Vasconcelos, I. M.; Carvalho, A. O.; Gomes, V. M. Partial characterization and antimicrobial activity of peptides from Amburana cearensis seeds against phytopathogenic fungi and yeasts. Acta Physiologiae Plantarum 2010, 32, 597. [CrossRef]

${ }^{23}$ Clerici, M. T. P. S.; Carvalho-Silva, L. B. Nutritional bioactive compounds and technological aspects of minor fruits grown in Brazil. Food Research International 2011, 44, 1658. [CrossRef]

${ }^{24}$ de Paula, C. A.; Coulson-Thomas, V. J.; Ferreira, J. G. Maza, P. K.; Suzuki, E.; Nakahata, A. M.; Nader, H. B.; Sampaio, M. U.; Oliva, M. L. Enterolobium contortisiliquum trypsin inhibitor (EcTI), a plant proteinase inhibitor, decreases in vitro cell adhesion and invasion by inhibition of Src protein-focal adhesion kinase (FAK) signaling pathways. The Journal of Biological Chemistry 2012, 287, 170. [CrossRef] [PubMed]

${ }^{25}$ Iganci, J. R. V. Pithecellobium dulce (Roxb.) Benth. Available at: <http://floradobrasil.jbrj.gov.br/reflora/listaB rasil/>. Accessed in: March 2016. [Link]

${ }^{26}$ Rao, G. N.; Nagender, A.; Satyanarayana, A.; Rao, D. G. Preparation, chemical composition and storage studies of quamachil (Pithecellobium dulce L.) aril powder. Journal of Food Science and Technology 2011, 48, 90. [CrossRef] [PubMed]

${ }^{27}$ Manna, P.; Bhattacharyya, S.; Das, J. Ghosh, J.; Sil, P. C. Phytomedicinal role of Pithecellobium dulce against $\mathrm{CCl}_{4}$-mediated hepatic oxidative impairments and necrotic cell death. Evidence-Based Complementary and Alternative Medicine 2011, 2011, 1. [CrossRef]

${ }^{28}$ Bradford, M. M. A rapid and sensitive method for the quantitation of microgram quantities of protein utilizing the principle of protein-dye binding. Analytical Biochemistry 1976, 72, 248. [CrossRef] [PubMed] 
${ }^{29}$ Baaziz, M. The activity and preliminary characterization of peroxidases in leaves of cultivars of date palm, Phoenix dactylifera $\mathrm{L}$. New Phytologist 1989, 111, 403. [CrossRef]

${ }^{30}$ Laemmli, U. K. Cleavage of structural proteins during the assembly of the head of bacteriophage T4. Nature 1970, 227, 680. [CrossRef] [PubMed]

${ }^{31}$ Caruso, C.; Chilosi, G.; Caporale, C.; Leonardi, L.; Bertini, L.; Magro, P.; Buonocore, V. Induction of pathogenesisrelated proteins in germinating wheat seeds infected with Fusarium culmorum. Plant Science 1999, 140, 87. [CrossRef]

32 Bernardes, A.; Textor, L. C.; Santos, J. C.; Cuadrado, N. H.; Kostetsky, E. Y.; Roig, M. G.; Bavro, V. N.; Muniz, J. R. C.; Shnyrov, V. L.; Polikarpov, I. Crystal structure analysis of peroxidase from the palm tree Chamaerops excels. Biochimie 2015, 111, 58. [CrossRef] [PubMed]

33 Bülbül, D.; Karakuş, E. Production and optimization of L-glutaminase enzyme from Hypocrea jecorina pure culture. Preparative Biochemistry \& Biotechnology 2013, 43, 385. [CrossRef] [PubMed]

${ }^{34}$ Grogan, G. Intragenomic enzyme complements. Journal of Molecular Catalysis B: Enzimatic 2011, 68, 22. [CrossRef]

35 Jach, G.; Soezer, N.; Schullehner, K.; Lalla, B.; Welters, P.; Mueller, A. Phytomining of plant enzymes for biotechnological use of fats and oils. European Journal of Lipid Science and Technology 2010, 112, 75. [CrossRef]

${ }^{36}$ Siqueira, F. G.; Ferreira Filho, E. X. Plant cell wall as a substrate for the production of enzymes with industrial applications. MiniReviews in Organic Chemistry 2010, 7, 54 [Link]

${ }^{37}$ Soetan, K. O.; Aiyelaagbe, O. O.; Olaiya, C. O. A review of the biochemical, biotechnological and other applications of enzymes. African Journal of Biotechnology 2010, 9, 382. [Link]
${ }^{38}$ Sawasdipuksa, N.; Lei, Z.; Summer, L. W.; Niyomploy, P.; Sangvanich, P. A Lysozyme with antifungal activity from Pithecellobium dulce seeds. Food Technology and Biotechnology 2011, 49, 489. [Link]

${ }^{39}$ Hiraga, S.; Sasaki, K.; Ito, H. Ohashi, Y. Matsui, H. A large family of class III plant peroxidases. Plant Cell Physiology 2001, 42, 462. [CrossRef] [PubMed]

${ }^{40}$ Fortea, M. I.; Pellicer, J. A.; SerranoMartínez, A.; López-Miranda, S.; LucasAbellán, C.; Núñez-Delicado, E. Red cabbage (Brassica oleracea) as a new source of highthermostable peroxidase. Journal of Agricultural and Food Chemistry 2012, 60, 10641. [CrossRef] [PubMed]

${ }^{41}$ González-Rábade, N.; Oliver-Salvador, M. C.; Salgado-Manjarrez, E.; Badillo-Corona, J. A. In vitro production of plant peroxidases - a review. Applied Biochemistry and Biotechnology 2012, 166, 1644. [CrossRef] [PubMed]

42 Battistuzzi, G.; D'Onofrio, M.; Loschi, L.; Sola, M. Isolation and characterization of two peroxidases from Cucumis sativus. Archives of Biochemistry and Biophysics 2001, 388, 100. [CrossRef] [PubMed]

${ }^{43}$ Andrews, J.; Adams, S. R.; Burton, K. S.; Edmondson, R. N. Partial purification of tomato fruit peroxidase and its effect on the mechanical properties of tomato fruit skin. Journal of Experimental Botany 2002, 53, 239. [CrossRef] [PubMed]

${ }^{44}$ Thongsook, T.; Barrett, D. M. Purification and partial characterization of broccoli (Brassica oleracea var. Italica) peroxidases. Journal of Agricultural and Food Chemistry 2005, 53, 3206. [CrossRef] [PubMed]

${ }^{45}$ Ngo, T.T. Peroxidase in chemical and biochemical analysis. Analytical Letters 2010, 43, 1572. [CrossRef]

${ }^{46}$ Balasubramanian, M.; Boopathy, R. Purification and characterization of peroxidases from liquid endosperm of Cocos nucifera (L.): biotransformation. Journal of Molecular Catalysis B: Enzymatic 2013, 90, 33. [CrossRef] 
${ }^{47}$ Kawano, T. Roles of the reactive oxygen species-generating peroxidase reactions in plant defense and growth induction. Plant Cell Reports 2003, 21, 829. [PubMed]

${ }^{48}$ Dŏgan, S.; Turan, P.; Dŏgan, M.; Arslan, O.; Alkan, M. Partial characterization of peroxidase from the leaves of thymbra plant (Thymbra spicata L. var. spicata). European Food Research and Technology 2007, 225, 865. [CrossRef]

${ }^{49}$ Deepa, S. S.; Arumughan, C. Purification and characterization of soluble peroxidase from oil palm (Elaeis guineensis Jacq.) leaf. Phytochemistry 2002, 61, 503. [CrossRef] [PubMed]

${ }^{50}$ Leon, J. C.; Alpeeva, I. S.; Chubar, T. A. Galaev, I. Y.; Csoregi, E. Sakharov, I. Y. Purification and substrate specificity of peroxidase from sweet potato tubers. Plant Science 2002, 163, 1011. [CrossRef]

${ }^{51}$ Caramyshev, A. V.; Firsova, Y. N.; Slastya, E. A. Tagev, A. A.; Potapenko, N. V.; Lobakova, E. S.; Pletjushkina, O. Y.; Sakharov, I. Y. Purification and characterization of windmill palm tree (Trachycarpus fortunei) peroxidase. Journal of Agricultural and Food Chemistry 2006, 54, 9888. [CrossRef] [PubMed]

${ }^{52}$ Ajila, C. M. Rao, U. J. S. P. Purification and characterization of black gram (Vigna mungo) husk peroxidase. Journal of Molecular Catalysis B: Enzymatic 2009, 60, 36. [CrossRef]

${ }^{53}$ Battistuzzi, G.; Bellei, M.; Bortolotti, C. A. Sola, M. Redox properties of heme peroxidases. Archives of Biochemistry and Biophysics 2010, 500, 21. [CrossRef] [PubMed]
${ }^{54}$ Pandey, V. P.; Dwivedi, U. N. Purification and characterization of peroxidase from Leucaena leucocephala, a tree legume. Journal of Molecular Catalysis B: Enzymatic 2011, 68, 168. [CrossRef]

${ }^{55}$ Pandey, V. P.; Singh, S.; Singh, R.; Dwivedi, U. N. Purification and characterization of peroxidase from Papaya (Carica papaya) fruit. Applied Biochemistry and Biotechnology 2012, 167, 367. [CrossRef] [PubMed]

${ }^{56}$ Hsu, S-K.; Chung, Y.-C.; Chang, C.-T.; Sung, $\mathrm{H}-\mathrm{Y}$. Purification and characterization of two acidic peroxidase isoforms from the sheaths of bamboo shoots. International Journal of Food Science \& Technology 2012, 47, 1872. [CrossRef]

${ }^{57}$ Nadaroglu, H.; Celebi, N.; Demir N.; Demir, $\mathrm{Y}$. Purification and characterisation of a plant peroxidase from rocket (Eruca vesicaria sbsp. Sativa) (Mill.) (syn. E. sativa) and effects of some chemicals on peroxidase activity in vitro. African Journal of Agricultural Research 2013, 8, 2520. [CrossRef]

${ }^{58}$ Khatun, S. Ashraduzzaman, M.; Rezaul Karim, M.; Pervin, F.; Absar, N.; Rosma, A. Purification and characterization of peroxidase from Moringa oleifera L. leaves. Bioresources 2012, 7, 3237. [Link]

${ }^{59}$ Sakharov, I. Y.; Sakharova, I. V. Extremely high stability of African oil palm tree peroxidase. Biochimica et Biophysica Acta (BBA) - Proteins and Proteomics 2002, 1598, 108. [CrossRef] [PubMed]

${ }^{60}$ Al-Senaidy, A. M.; Ismael, M. A. Purification and characterization of membrane-bound peroxidase from date palm leaves (Phoenix dactylifera L.). Saudi Journal of Biological Sciences, 2011, 18, 293. [CrossRef] 